\title{
Review on Role of Soil and Water Conservation Measures on Soil Physico Chemical Properties and Its Implication to Climate Change Mitigation and Adaptation
}

\author{
Tadele Geremu \\ Oromia Agricultural Research Institute, Mechara Agricultural Research Center, P.O.Box, 19, Mechara, Ethiopia
}

\begin{abstract}
Soil degradation is a global threat. Developing countries are more severely affected by soil degradation than developed countries. Ethiopia, one of the developing countries in eastern Africa, is highly threatened by soil degradation problems. The soil degradation problem has had serious consequences in Ethiopia such as occurrence of persistent food insecurity, economic losses and various environmental hazards such as recurrent drought and increases vulnerability of people to the adverse effects of climate variability and change. To overcome these problems, integrated soil and water conservation has been implemented in the country. Thus many studies have been conducted with regards to soil and water conservation which influences soil physical and chemical properties and on climate change adaption and mitigation. Therefore, this review papers was aimed to assess role of soil and water conservation on soil physical and chemical properties and it's implication to climate change adaptation and mitigation. Different studies showed that soil physical and chemical properties such as Soil texture (sand, silt, clay), Moisture volume (\%), FC (\%), PWP (\%), AWC (\%), OC, TN, pH, EC, CEC Ava_P, and Ava_K, (EB: K ${ }^{+}$, $\mathrm{Ca}^{2+}$, and $\mathrm{Mg}^{2+}$ ) were improved in different agro ecologies. In addition to this, soil treated with soil and water conservation stored more organic carbon as compared to non treated soil. Soil and water conservation also contributed to improve yield and yield component of crops in areas where serious soil erosion and also in moisture deficit areas. Thus, the studies have been showed that the people's ability to adopted in climate change. Therefore soil and water conservation could improve soil physical and chemical properties, climate change mitigation and adaptation in the country.
\end{abstract}

Keywords: Adaptation, Mitigation, Phyisco chemical properties, soil and water conservation

DOI: $10.7176 /$ JNSR/9-11-04

Publication date:June $30^{\text {th }} 2019$

\section{INTRODUCTION}

Soil degradation is a global threat (Cerdà et al., 2010; Mighall et al., 2012; de Souza Braz et al., 2013; Wang et al., 2013). It has been affecting about two billion hectares of land (Oldeman et al., 1991). While no region is immune, developing countries are more severely affected by soil degradation than developed countries. Ethiopia, one of the developing countries in eastern Africa, is highly threatened by soil degradation problems (Hurni, 1993; Shiferaw \& Holden, 1999; Hurni et al., 2007). Soil degradation is a serious problem in Ethiopia, particularly in the highlands, where population density is high and the bulk of crop production occurs (Hurni, 1993; Shiferaw \& Holden, 1999; Hurni et al.,2007; Haile and Fetene, 2012; Mekuria et al., 2012; Meshesha et al., 2012; Haregeweyn et al., 2013; Karltun et al., 2013;Belay et al., 2014). The pressure from human and livestock populations, coupled with biophysical, social, economic, and political factors, has caused severe degradation of resources (Hurni, 1993; Sonneveld, 2002; Girmay et al., 2008). Depletion of soil organic matter (SOM) and nutrients, salinization, and soil erosion by water are the most critical forms of soil degradation (Bewket, 2003; Girmay et al., 2008) and are exacerbated by deforestation.

The severity of this land degradation process makes large areas unsuitable for agricultural production, because the topsoil and even part of the sub-soil in some areas has been removed, and stones or bare rock are left at the surface (Esser et al., 2002). The land degradation problem has had serious consequences in Ethiopia such as occurrence of persistent food insecurity, economic losses and various environmental hazards such as recurrent drought (Bekele and Holden, 1999). As noted by Pimentel et al. (1995), erosion adversely affects crop productivity by reducing water availability, water-holding capacity of the soil, nutrient levels, soil organic matter and soil depth. Research results confirmed that soil nutrient depletion caused by erosion is the major cause for decline of agricultural production (Bekele and Holden, 1998; Abay et al., 2016). Deforestation and conversion of marginal land to agriculture has been followed by severe soil erosion that has caused crop production losses, which in turn result in economic losses (Bojö and Cassels, 1995). For example, due to soil and nutrient loss through erosion, Ethiopia has been annually losing about US\$ 106 million (Bojö and Cassels, 1995).

Soil degradation also increases vulnerability of people to the adverse effects of climate variability and change, by reducing soil organic carbon (SOC) concentration and water holding capacity, which in turn reduces agricultural productivity and local resource assets (TerrAfrica, 2009). The downward spiral adversely affects the adaptive capacity of the people to climate variability and change (Girmay et al., 2008; TerrAfrica, 2009). 
Soil organic carbon (SOC) plays a vital role within the overall carbon cycle (Van Oost et al., 2007). Central to the present concept, soil sequesters averagely three hundred times of carbon created by industrial burning of fossil fuels (Lal, 2005). So any slight changes to SOC can have a negative effect on provision of system services. Being preferentially found on the surfaces, SOC has comparatively lower density, making it easier for it to be carried off by runoff. Several studies have shown that the typical loss of SOC by water erosion annually is 1-5 pentagram of carbon that is consequently deposited at the lower areas of a catchment (Berhe, 2012).

SOC includes organic compounds (i'e., plant, animal and microbial residues in any stage of decay) that are highly enriched in carbon (Lal, 2008). Consequently the role of SOC is important in edaphic factors like physical, chemical and biological properties of soil. Thus soil organic matter (SOM) determines soil quality, physical properties, crop nutrition and the link between these (Bergmann 1992; Loveland and Webb 2003). The soil physical properties affected by soil OM include aggregate stability, infiltration, water-holding capacity, soil workability, bulk density, aeration and water movement (Bergmann 1992; Loveland and Webb 2003). Soil carbon is affected on a spatial and temporal scale by climatical, edaphic, biotic and lithological factors which influence the balance between the gains and losses of soil carbon (Kurgat, 2011).

Girmay et al. (2008) estimated the historic SOC loss from rangelands and croplands of Ethiopia over the last 50 years to be $230-670 \mathrm{TgC}(\mathrm{Tg}=$ teragram $=1012 \mathrm{~g}=$ million metric ton $)$. Therefore, soil degradation will continue to be a serious threat to the finite land resource if prudent land use and effective soil management strategies to increase SOC concentration and restore soil quality are not implemented.

Sustainable soil management technologies (e.g., appropriate soil and water conservation (SWC) measures, afforestation of degraded soils, water harvesting, crop rotations, crop residue mulching along with cover cropping, agroforestry, and integrated nutrient management) can enhance the SOC stock, reduce soil degradation, and decrease soil's vulnerability to climate change. In addition, judicious soil management can increase people's capacity to adapt and mitigate climate change through $\mathrm{C}$ sequestration and greenhouse gas (GHG) emissions reduction (Lal, 2004; Vagen et al., 2005; TerrAfrica, 2009). World croplands can sequester $0.02-0.76 \mathrm{MgCha}^{1}$ year ${ }^{1}$ by adopting recommended management practices (Lal, 2001). Girmay et al. (2008) estimated the historical SOC sequestration potential of croplands in Ethiopia through adapting soil restorative measures at $215-638 \mathrm{Tg}$ $\mathrm{C}$ over a period of 50 years. Soil $\mathrm{C}$ sequestration can improve soil quality; restore degraded ecosystems, and increase agronomic/biomass productivity (Lal et al., 2003). Thus, C sequestration is often termed as a win-win or no-regrets strategy (Lal et al., 2003; Girmay et al., 2008). However, it requires the selection and implementation of technologies that are appropriate to specific soils and eco regions (Girmay et al., 2008).

Therefore the objective of this review is to assess role of soil and water conservation on soil physical and chemical properties and it's implication to climate change adaptation and mitigation in Ethiopia.

\section{METHODOLOGY OF REVIEW}

To the success of this work, different sources such as journals, proceedings, thesis works and reports related to soil and water conservation and climate change adaptation and mitigation have been used.

\section{EFFECT OF SOIL AND WATER CONSERVATION ON PROPERTIES OF SOIL}

3.1 Effect of Soil and Water Conservation on Chemical Properties of Soil

Table 1 Effect of SWC on chemical soil properties

\begin{tabular}{|c|c|c|c|c|}
\hline Type of SWC & $\begin{array}{l}\text { Studied chemical } \\
\text { properties of soil }\end{array}$ & $\begin{array}{l}\text { Improved chemical } \\
\text { properties of soil }\end{array}$ & Studied area & Source \\
\hline Graded stone bund & $\mathrm{OM}, \mathrm{TN}, \mathrm{pH}$, and CEC & $\mathrm{OM}, \mathrm{TN}, \mathrm{pH}$, and CEC & $\begin{array}{l}\text { Adaa } \\
\text { district }\end{array}$ & $\begin{array}{l}\text { Abay et } \\
\text { al., } 2016\end{array}$ \\
\hline $\begin{array}{l}\text { Stone faced soil } \\
\text { bund and soil bund }\end{array}$ & $\begin{array}{l}\mathrm{OC}, \mathrm{TN}, \mathrm{pH}, \mathrm{EC}, \mathrm{CEC} \\
\text { Ava_P, and Ava_ K, } \\
(\mathrm{EB})\left(\mathrm{K}^{+}, \mathrm{Ca}^{2+}, \text { and }\right. \\
\left.\mathrm{Mg}^{2+}\right)\end{array}$ & $\begin{array}{l}\mathrm{OC}, \mathrm{TN}, \mathrm{pH}, \mathrm{EC}, \mathrm{CEC} \\
\text { Ava } \mathrm{P} \text {, and Ava } \mathrm{K},(\mathrm{EB}) \\
\left(\mathrm{K}^{+}, \mathrm{Ca}^{2+} \text {, and } \mathrm{Mg}^{2+}\right)\end{array}$ & $\begin{array}{l}\text { Gonder zuria } \\
\text { district } \\
\text { Ambachia } \\
\text { Watershed }\end{array}$ & $\begin{array}{l}\text { Worku, } \\
2017\end{array}$ \\
\hline $\begin{array}{l}\text { Level soil bund and } \\
\text { stone bund }\end{array}$ & $\begin{array}{l}\text { SOC, } \mathrm{TN}, \quad \mathrm{P} \text { avai, } \\
\mathrm{K} \text { avail, } \mathrm{Ph}, \mathrm{CEC},\end{array}$ & $\mathrm{TN}$ & $\begin{array}{l}\text { Dawuro zone, } \\
\text { Loma district }\end{array}$ & $\begin{array}{l}\text { Kebede et } \\
\text { al., } 2011\end{array}$ \\
\hline Terraces & $\begin{array}{l}\mathrm{OM}, \mathrm{TN}, \mathrm{pH}, \mathrm{CEC} \\
\text { Ava_P, and (EB) }\left(\mathrm{K}^{+},\right. \\
\left.\mathrm{Na}^{+}, \mathrm{Ca}^{2+} \text {, and } \mathrm{Mg}^{2+}\right)\end{array}$ & $\begin{array}{l}\text { OM, TN, } \mathrm{pH}, \text { CEC Ava_P, } \\
\text { and, (EB) }\left(\mathrm{Na}^{+} \mathrm{K}^{+}, \mathrm{Ca}^{2+},\right. \\
\left.\text { and } \mathrm{Mg}^{2+}\right)\end{array}$ & $\begin{array}{l}\text { Dembecha } \\
\text { district, Anjeni } \\
\text { watershed }\end{array}$ & $\begin{array}{l}\text { Tadele et } \\
\text { al., } 2013\end{array}$ \\
\hline $\begin{array}{l}\text { Lands treated with } \\
\text { Sesbania and } \\
\text { elephant grass }\end{array}$ & $\begin{array}{l}\mathrm{OM}, \mathrm{TN}, \mathrm{pH}, \mathrm{CEC} \\
\text { Ava_P, and (EB) }\left(\mathrm{K}^{+},\right. \\
\left.\mathrm{Na}^{+}, \mathrm{Ca}^{2+} \text {, and } \mathrm{Mg}^{2+}\right)\end{array}$ & $\begin{array}{l}\text { OM, TN, } \mathrm{pH}, \mathrm{CEC} \text { Ava_P, } \\
\text { and }(\mathrm{EB})\left(\mathrm{K}^{+}, \mathrm{Na}^{+}, \mathrm{Ca}^{2+},\right. \\
\left.\text { and } \mathrm{Mg}^{2+}\right)\end{array}$ & $\begin{array}{l}\text { Lemo district, } \\
\text { Hadiya zone }\end{array}$ & $\begin{array}{l}\text { Tamrat et } \\
\text { al., } 2018\end{array}$ \\
\hline $\begin{array}{l}\text { Manure, Soil bund, } \\
\text { integrated manure } \\
\text { and soil bund }\end{array}$ & $\begin{array}{l}\text { TN, pH, CEC Ava_P, } \\
\text { OM }\end{array}$ & TN, pH, CEC Ava_P, OM & $\begin{array}{l}\text { Dembecha } \\
\text { woreda, Zikri } \\
\text { watershed }\end{array}$ & $\begin{array}{l}\text { Yihenew } \\
\text { et al., } \\
2015\end{array}$ \\
\hline
\end{tabular}


Several studies recognized that, physical SWC showed a significant difference on chemical properties of soil between conserved and non conserved plot of land. According to the study conducted by (Abay et al., 2016) the graded stone bunds have shown significant improvement in chemical soil properties such as soil OM, TN, $\mathrm{pH}$, and CEC. Moreover, the high OM content of farm plots with SWC practices affect more positively the soil properties as compared to the non conserved farm plots. Also, variation was also significant along slope gradient for some chemicals properties. Worku, H (2017) indicated that, physical SWC (stone faced soil bund and soil bund) is promising in protecting the cultivated land from erosion and the associated nutrient depletion. With regard to analysis of soil characteristics in treated and untreated plots, SOC and total N were higher while BD was lower under the conserved farm. Yonas et al., 2017 also reported that, that the effectiveness of soil and water conservation improves significantly the soil chemical properties (soil $\mathrm{pH}, \mathrm{K}^{+}$, available $\mathrm{P}, \mathrm{SOC}, \mathrm{TN}$, and CEC) than in the adjacent without SWC treatment. This indicates the positive impacts of SWC practices in improving the nutrient status. OM, TN, pH, CEC Ava_P, and EB also significantly improved by biological SWC. However, Kebede et $a l ., 2011$ reported that, less SOC, Pavai, $\mathrm{pH}$ is measured from conserved plot of land. These perhaps due to: the difference in the past land degradation resulting from continuous cultivation, extractive plant harvest and soil erosion. Alemayehu, A 2007 also confirm in Anjeni watershed that Pavail on non terraced land was higher than the terraced. The significantly low soil $\mathrm{pH}$ in level stone bund and soil bund compared to the respective adjacentnonterraced cropland were probably due to loss of relatively more basic cation resulted from erosion before the structures built and did not restore yet after the structures. Under a continuous cropping system soil acidity increases due to the gradual replacement of basic cations by aluminum (Zougmore et al., 2002).

SWC structures are practically used as support for agronomic and soil management (Morgan, 2005) and considered as the first defense line. Thus, they alone are less likely to improve soil properties significantly under similar management to non terraced. Zougmore et al., 2009 has reported that combining stone rows barriers to run-off with the application of compost was significantly controlled erosion and reduced organic $\mathrm{C}$ and nutrient losses than compost or stone row alone.

\subsection{Effect of Soil and Water Conservation on Physical Properties of Soil}

Various studies conducted to evaluate the structural and biological soil and water conservation and on physical soil properties. According to those studies, the percentage of clay content of soil increases with a soil treated with SWC structure, and decreasing sand particles of soil. The decrease in soil BD due to SWC practices at would result in greater water infiltration rates which in turn minimize runoff velocity, thus, sediments and organic matter removal. As a consequence OM accumulation improves a soil physical structure which promotes crop root abundance, crop stand, crop production and better crop residues at the conserved field plot. The land that treated with SWC measures improves the soil moisture content which is a key factor affecting agricultural production in water limited environments.

Table 2 Effect of SWC on physical soil properties

\begin{tabular}{|c|c|c|c|c|}
\hline Type of SWC & $\begin{array}{l}\text { Studied physical } \\
\text { properties of soil }\end{array}$ & $\begin{array}{l}\text { Improved physical } \\
\text { properties of soil }\end{array}$ & Studied area & Source \\
\hline Graded stone bund & $\mathrm{BD}, \mathrm{MC}$ & $\mathrm{BD}, \mathrm{MC}$ & $\begin{array}{l}\text { Adaa } \\
\text { district }\end{array}$ & $\begin{array}{l}\text { Abay et al., } \\
2016\end{array}$ \\
\hline $\begin{array}{l}\text { Level soil bund and } \\
\text { stone bund }\end{array}$ & $\begin{array}{l}\text { Soil texture (sand, silt, } \\
\text { clay) }\end{array}$ & $\begin{array}{l}\text { Soil texture (sand, silt, } \\
\text { clay) }\end{array}$ & $\begin{array}{l}\text { Dawuro zone, } \\
\text { Loma district }\end{array}$ & $\begin{array}{l}\text { Kebede et al., } \\
2011\end{array}$ \\
\hline Fanya Juu & $\begin{array}{l}\text { Soil texture (sand, silt, } \\
\text { clay), BD }\end{array}$ & $\begin{array}{l}\text { Soil texture (sand, silt, } \\
\text { clay), BD }\end{array}$ & $\begin{array}{l}\text { Ambo district, } \\
\text { Goromti } \\
\text { watershed }\end{array}$ & $\begin{array}{l}\text { Worku et al., } \\
2012\end{array}$ \\
\hline Fan & $\begin{array}{l}\text { Soil texture (sand, silt, } \\
\text { clay), Moisture volume } \\
(\%), \quad \mathrm{FC}(\%), \operatorname{PWP}(\%) \text {, } \\
\text { AWC }(\%)\end{array}$ & $\begin{array}{l}\text { Soil texture (sand, silt, } \\
\text { clay), Moisture volume } \\
(\%), \mathrm{FC}(\%), \operatorname{PWP}(\%), \\
\text { AWC }(\%)\end{array}$ & $\begin{array}{l}\text { Dembecha } \\
\text { woreda, Anjeni } \\
\text { watershed }\end{array}$ & $\begin{array}{l}\text { Daniel et al., } \\
2015\end{array}$ \\
\hline $\begin{array}{ll}\text { Lands treated with } \\
\text { Sesbania } & \text { and } \\
\text { elephant grass } & \\
\end{array}$ & $\begin{array}{l}\text { Soil texture (sand, silt, } \\
\text { clay), BD }\end{array}$ & $\begin{array}{l}\text { Soil texture (sand, silt, } \\
\text { clay), BD }\end{array}$ & $\begin{array}{l}\text { Lemo District of } \\
\text { Southern } \\
\text { Ethiopia }\end{array}$ & $\begin{array}{l}\text { Tamrat et al., } \\
2018\end{array}$ \\
\hline $\begin{array}{l}\text { Manure, Soil bund, } \\
\text { integrated manure } \\
\text { and soil bund }\end{array}$ & $\mathrm{BD}$ & $\mathrm{BD}$ & $\begin{array}{l}\text { Dembecha } \\
\text { woreda, Zikri } \\
\text { watershed }\end{array}$ & $\begin{array}{l}\text { Yihenew } \\
\text { al., } 2015\end{array}$ \\
\hline
\end{tabular}

According to (Abay, et al) Bulk density and moisture content of treated soil is increased. Similar results also reported by (worku et al., 2012) and increased the percentage of clay contents was observed. This result also confirms the presence of higher clay fraction of conserved soil due to deposition from the upper slope (Regina et al., 2004). Soil moisture shows significance variation between treated and non treated land. SOM is positively correlated with $\mathrm{MC}$ while it is inversely correlated with soil BD. The recorded percentage of sand is lower for soil 
treated with SWC while higher percentage of clay for treated soil. Those results confirm the findings by Lemma et al. (2015). These may be due to soil particles resistance to detachment, and susceptibility to transportation. Gebremichael et al. (2005) reported that selective removal of soil particles to steeper slopes leave behind coarser materials (sand, gravel and stones), while the transported material is deposited as the slope steepness decreases. Sandy soils are less cohesive than clayey soils and thus aggregates with high sand content are more easily detached; silty soils derived from loess parent material are the most erodible type of soil (Blanco and Lal, 2008). Integrated application of manure and soil bund also improves soil bulk density (Yihenew et al., 2015)

There is an improvement in hydrological properties in soils of the conserved than those in the non-conserved land (Daniel et al., 2015). The volumetric moisture content, field capacity, permanent wilting point and available water content of soils of the conserved land is higher than the non conserved land. A study by World Neighbors (2000) in Guatemala, Honduras, and Nicaragua reported a 3-15\% increase in AWC by the adoption of ecologically sound SWC practices. Improvement in AWC is important because such soils buffer water during periods of water deficit and could significantly improve agronomic productivity of rainfed agriculture. However, the agronomic and economic performances of SWC measures in tropical regions are highly dependent on the amount and distribution of precipitation (Benites \& Ofori, 1993). Daniel et al., 2015 reported that, the highest FC and AWC, and also the lowest PWP is recorded from a soil treated with SWC. These trends suggest a positive impact of SWC measures on MC, FC, PWP and AWC.

The highest quantity of clay fractions is recorded under lands treated with elephant grass and sesbania whereas the lowest was in the adjacent degraded grazing land. A similar amount of clay fraction was found at lands treated with elephant grass and sesbania. This indicates elephant grass and sesbania have equal potential to minimize rates of erosion, keep clay materials in its original place, and capture eroded clay materials. The highest value of bulk density is observed at degraded grazing land and lowest at land treated with elephant grass and sesbania. Further, elephant grass and sesbania had similar effects on soil bulk density. Perhaps, the achieved soil bulk density improvement is due to organic matter addition from the plants, reduction of physical soil loss, and exclusion of grazing practices and human interference.

\section{ROLE OF SWC TO MITIGATE CLIMATE CHANGE.}

There is much concern that the increasing concentration of greenhouse gases in general, and carbon dioxide in particular contributes to global warming by trapping long-wave radiation reflected from the earth's surface. Over the past 150 years, the amount of carbon in the atmosphere has increased by $30 \%$. Most scientists believe that there is a direct relationship between increased levels of carbon dioxide in the atmosphere and rising global temperature (Stavins and Richards, 2005).

One proposed method to reduce atmospheric carbon dioxide is to increase the global storage of carbon in soils. Though, soil carbon storage is a win-win strategy. It mitigates climate change by offsetting anthropogenic emissions; improves the environment, especially the quality of natural waters; enhances soil quality; improves agronomic productivity; and advances food security (FAO, 2005; Lal, 2009; Adesodun and Odejim, 2010; Kumar et al., 2009). Soils store $1502 \mathrm{Gt}$ carbon (Jobbagy and Jackson, 2000), an amount that is two times greater than the amount found in the atmospheric carbon pool (Battle et al., 2000; Lal, 2004). In addition to carbon storage, the turnover time of organic carbon is important in understanding the role of soils in the global carbon cycle. Thus, soil carbon sequestration through changes in land use and management is one of the important strategies to mitigate the global greenhouse effect. Important land uses and practices with the potential to sequester soil organic carbon include conversion of cropland to pastoral and forest lands, conventional tillage to conservation tillage or no-tillage, and no manure use to regular addition of manure. However, food security needs for the world teeming population make conversion of cropland to forestland unsustainable. Therefore, increased food demands call for management of croplands to ensure food security and at the same time enhanced soil organic carbon sink within the soil to minimized atmospheric emission of $\mathrm{CO}_{2}$ (Adesodun and Odejimi, 2010). In this case, afforestation and conservation programs have been made in the last three decades (Badege, 2001). In addition to this there was a huge areal closure activity in the country for the purpose of rehabilitating degraded lands which have their own role in increasing soil carbon stock.

According to the study conducted in Anjeni watershed, higher soil organic carbon concentration and soil organic carbon stock recorded from a soil treated with SWC than non conserved soil (Daniel et al., 2015). The soil and water conservation system reduce surface runoff and soil loss, retain water that enhances crop growth and contributes to SOC input. Thus several studies confirm that, SOM and SOC are increased because of conservation measures. However, Kebede et al., 2011 disagree with these results that, the concentration of SOC is decreased from conserved lands (treated with level soil bund and stone bunds). Thus he suggests that, SOC is less because of intensive tillage, continuous cropping, removal of crop residues, and low organic carbon input in croplands.

\section{CLIMATE CHANGE ADAPTATION}

Ethiopia is extremely vulnerable to the impacts of climate change (Aklilu et al., 2009). Similarly, Burnett (2013) 
reported that Ethiopia has been identified as one of the most vulnerable countries to climate variability and change, and is frequently faced with climate-related hazards, commonly drought and floods. Since the early 1980s, the country has suffered seven major droughts five of which have led to famines in addition to dozens of local droughts. Major floods also occurred in different parts of the country in 1988, 1993, 1994, 1995, 1996 and 2006 (World Bank, 2010). Vulnerability is not the same for populations living under different social, economic,political, institutional and environmental conditions. For example, pastoralists in Yabello district tend to bemore vulnerable to climate change than farmers (Oxfam international, 2010). Several studies indicate that soil and water conservation measures used as a climate change adaptation through encouraging crop yield, even in areas where moisture deficit affect crop yields. SWC used to save moisture in the soil and make conducive environment for plants. Therefore it provides a yield advantage.

Table 3 Effect of SWC on yield improvements

\begin{tabular}{|c|c|c|c|c|}
\hline Type of SWC & $\begin{array}{l}\text { Studied } \\
\text { crop }\end{array}$ & $\begin{array}{l}\text { Improved } \\
\text { parameters }\end{array}$ & Studied area & Source \\
\hline Terraces & $\begin{array}{l}\text { Wheat and } \\
\text { maize }\end{array}$ & $\begin{array}{l}\text { Grain yield, } \\
\text { biomass yield and } \\
\text { plant height }\end{array}$ & $\begin{array}{l}\text { Dembecha district, } \\
\text { Anjeni watershed }\end{array}$ & $\begin{array}{l}\text { Tadele et al., } \\
2013\end{array}$ \\
\hline Level soil bund & $\begin{array}{l}\text { Maize and } \\
\text { sorghum }\end{array}$ & Yield & $\begin{array}{l}\text { Hawi Gudina district, } \\
\text { Oromia region }\end{array}$ & $\begin{array}{l}\text { Eshetu et al., } \\
2016 \mathrm{~b}\end{array}$ \\
\hline Fanya juu and Fanya chin & Maize & Yield & $\begin{array}{l}\text { Daro labu district, } \\
\text { Oromia region }\end{array}$ & $\begin{array}{l}\text { Eshetu et al., } \\
2016 \mathrm{a}\end{array}$ \\
\hline $\begin{array}{l}\text { Negarim and semi circular } \\
\text { structure with mulch }\end{array}$ & Banana & $\begin{array}{l}\text { Yield and yield } \\
\text { components }\end{array}$ & $\begin{array}{l}\text { Daro labu district, } \\
\text { Oromia region }\end{array}$ & $\begin{array}{l}\text { Tadele et al., } \\
2016\end{array}$ \\
\hline Tied ridge & maize & $\begin{array}{l}\text { Yield and yield } \\
\text { components }\end{array}$ & $\begin{array}{l}\text { Sankurra } \\
\text { SNNPR: } \\
\text { district, } \\
\text { region }\end{array}$ & $\begin{array}{l}\text { Dagnaw et al., } \\
2018 ; \\
\text { Solomon, } \\
2015\end{array}$ \\
\hline Tied ridges with mulch & sorghum & $\begin{array}{l}\text { Yield and yield } \\
\text { components }\end{array}$ & $\begin{array}{l}\text { Alamata district, } \\
\text { tigray region }\end{array}$ & $\begin{array}{l}\text { Berhanu and } \\
\text { Kidane, } 2013\end{array}$ \\
\hline $\begin{array}{l}\text { Circular Pitting, Open Ridge, } \\
\text { Tied Ridge, Half Moon }\end{array}$ & sorghum & $\begin{array}{l}\text { Yield and yield } \\
\text { components }\end{array}$ & $\begin{array}{ll}\text { Alduba } & \text { district } \\
\text { SNNPR } & \end{array}$ & $\begin{array}{l}\text { Tekle and } \\
\text { Wedajo, } 2015\end{array}$ \\
\hline
\end{tabular}

Eshetu et al., 2016a and Eshetu et al., 2016b reported that the adoption ofFanya juu and Fanya chin and soil bund moisture conservation structure improves crop production and increase the yield advantage as Soil moisture/rainfall decrease. Also considered conserving soil moisture recommended with early maturing and drought resistant maize variety or other annual crops to be further scaled up in moisture stress areas. Also Dagnaw et al., 2018 indicated that Open end tied ridge planting on the furrow showed a promising result on maize grain yield and soil moisture conservation as compared to traditional practice. Therefore, tied ridge as in-situ moisture conservation is effective measures in storing $33.7 \%$ additional soil water for the next cropping season as compared to traditional practice. It is recommended that, the practice should be demonstrated and scaled up in moisture stress areas of the country. Terraces improve the yield and yield components of maize and wheat (Tadele et al., 2013). The study of SWC also extends to fruit crops which is affected by moisture deficit due to recent climate change occurred. Therefore, Negarim and semicircular micro catchments with mulch increases the yield and yield components of banana in moisture deficit areas (Tadele et al., 2017). Tekle and Wedajo, 2015 reported that critical to use and apply soil moisture conservation practices in the current agricultural production system and in order to use the available in situ water efficiently and effectively to bring improved grain and biomass yield and also improved productivity and production of sorghum in a sustainable manner. Solomon, 2015 recommend that Water conservation techniques at farm level are essential options for the semi arid area for improving yield through better soil water storage. With the current change in global climate, adaptation methods like the use of conservation approaches are to be implemented if the agriculture sector is to continue to meet the ever increasing food demand especially in developing countries like Ethiopia.

Generally, the current condition of Ethiopian climate change has been changing from time to time which affects the crop production, livestock and all natural resources. The recurrent occurrence of drought in the country leads to famine in arid and semi arid areas. In order to adapt to the change, the farmers adopt SWC on their farm lands and also on area enclosure. Thus, according to the study conducted by many authors, application of SWC provides food and feed even if below of its potential.

\section{SUMMARY AND CONCLUSION}

Ethiopia, one of the developing countries in eastern Africa, is highly threatened by soil degradation problems. Depletion of soil organic matter (SOM) and nutrients, salinization, and soil erosion by water are the most critical forms of soil degradation. SWC measures, afforestation of degraded soils, water harvesting, crop rotations; crop 
residue mulching along with cover cropping, agroforestry, and integrated nutrient management can enhance the SOC stock, reduce soil degradation, and decrease soil's vulnerability to climate change. In addition, judicious soil management can increase people's capacity to adapt and mitigate climate change through $\mathrm{C}$ sequestration and greenhouse gas $(\mathrm{GHG})$ emissions reduction.

In Ethiopia different SWC has been implemented under different land use system to rehabilitate degraded lands, enhance soil productivity, improve micro climate, and improve crop yields under moisture stress areas. In line with this, different researches have been conducted in different agro ecologies to assess the role of SWC on soil physico chemical properties and its role on to climate mitigation adaptation. Among physical SWC, soil bund, stone bund, stone face soil bund, Fanya juu, Fanya chin, terraces, and among biological SWC plantation of elephant grass and sesbania was implemented. Also integrated soil bund with manure demonstrated to improve soil fertility. According to the research conducted in the country, both biological and physical SWC has improved both physical and chemical soil properties. However the integrated SWC was more effective rather than individual conservation measures. According to the research reviewed, a few considerations were given to physical soil properties as affected by SWC. Physical soil properties affect chemical soil properties.

$\mathrm{SWC}$ is act as a climate change mitigation strategies through reduction of $\mathrm{CO}_{2}$ emission to the atmosphere which is in particular contributes to global warming. According to the study conducted in the country, higher soil organic carbon concentration and soil organic carbon stock recorded from a soil treated with SWC than non conserved soil. But most studies have been conducted to determine SOM concentration of the soil, thus SWC increases SOM and in directly store more carbon in soil. However many studies disagree with such finds that only SWC cannot significantly increase SOM alone. Because, it needs an integrated approach of biological and physical SWC to enhance SOM

Ethiopia is the most vulnerable countries to climate variability and change, and is frequently faced with climate-related hazards, commonly drought and floods which lead to famine. SWC plays a major role on climate adaptation in order to produce yields especially under moisture deficit areas. The most effective SWC to harvest water were tied ridges with mulch, Circular Pitting, Open Ridge, Half Moon terraces, level soil bund, Fanya juu and Fanya chin, Negarim and semi circular structure with mulch were implemented with different commodities and gives yield advantages than un conserved water on the fields. Even if more consideration were given to physical SWC, soil physical and chemical soil properties were improved and indirectly mitigate climate changes in the country. In addition to this, small holder farmers produce crop yield under limited moisture content of soil by harvesting the limited rainfall. Therefore soil and water conservation could be demonstrated and popularized on all land uses

\section{REFERENCES}

Abay, C., Abdu A, Tefera M. 2016. Effects of Graded Stone Bunds on Selected Soil Properties in the Central Highlands of Ethiopia. Int. J. Nat. Res. Ecol. Manag, 1(2):42-50.

Adesodun J and Odejim O. 2010. Carbon-Nitrogen sequestration potentials and structural stability of a Tropical Alfisol as influenced by Pig-Composted Manure. Journal of International Agro physics, 24:333-338.

Aklilu, K., Rovin, K. and Hardee, K. 2009. Linking Population, Fertility and Family Planning with Adaptation to Climate Change: Views from Ethiopia.

Alemayehu Assefa. 2007. Impact of terrace development and management on soil properties in Anjeni area, West Gojam. M.Sc Thesis, Addis Ababa University, Ethiopia.

Badege B . 2001. Deforestation and land degradation in the Ethiopian highlands: A strategy for physical recovery. Northeast African Studies, 8(1):7-26.

Battle, M., Bender M, Tans P, White J, Ellis J, Conway T and Francey R. 2000. Global Carbon sinks and their variability inferred from atmospheric $\mathrm{O}_{2}$ and C Science. 287:2467-2470.

Bekele S, Holden S. 1998. Resource degradation and adoption of land conservation technologies in the Ethiopian Highlands: A case study in Andit Tid, North Shewa. Agricultural Economics. 18:233-247

Bekele S, Holden S. 1999. Soil erosion and smallholders' conservation decisions in the highlands of Ethiopia. World Development. 27(4):739-752.

Belay KT, Van Rompaey A, Poesen J, Van Bruyssel S, Deckers J, Amare K. 2014. Spatial analysis of land cover changes in Eastern.

Benites JR, Ofori CS. 1993. Crop production through conservationeffective tillage in the tropics. Soil \& Tillage Research 27: 9-33.

Berhanu, A, A., Kidane, G 2013. Response of sorghum yield to mulching and planting methods on dry land areas of Tigray, Ethiopia. Open Science Repository Agriculture.

Blanco H, Lal R. 2008. Principles of Soil Conservation and Management. Springer.

Burnett, D. 2013. Final report: Stage 2 - Supporting Climate Resilient Value Chains. Tigray (Ethiopia) from 1965 to 2007: are there signs of a forest transition?. Land Degradation and Development (in press) DOI: 10.1002/ ldr. 2275 
Bergmann, W. 1992. Nutritional disorders of plant: Development, visual and analytical diagnosis, New York.

Berhe, A., Harden, J. W., Torn, M. S., Kleber, M., Burton, S. D., and Harte, J. 2012. Persistence of soil organic matter in eroding versus depositional landform positions. Journal of Geophysics: Biogeosciences, 117(2).

Bewket, W. 2003. Towards integrated watershed management in highland Ethiopia: the Chemoga watershed case study. Wageningen University, Wageningen: The Netherlands; ISBN 90-5808-870-7.

Bojo, J., Cassells, D. 1995. Land degradation and rehabilitation in Ethiopia: A reassessment. AFTES, Working Paper No. 17, World Bank.

C. Regina, C. Luiza, V. Fla, J. Luiza, Q. Romild, F. Paiva. Terezinha, S. MonteiroLucine, Z Sousa and K. Bart. 2004. "Varia-tion of carbon and nitrogen cycling processes along a topo-graphic gradient in a central Amazonian forest”. Global Change Biology. 10: 592-600.

Cerda, A., Hooke, J., Romero-Diaz, A., Montanarella, L., Lavee, H. 2010. Soil erosion on Mediterranean typeecosystems. Land Degradation and Development. DOI: 10.10021.dr.968.

Dagnaw, A., Bagegnehu B., Abiy, G. 2018. On-farm Verification of the Soil Moisture and Yield Response of Tied Ridge on Maize Production in Dry Areas of SNNPR, Ethiopia. Journal of Environment and Earth Science. $8(5)$.

Daniel, M., Woldeamlak, B., Rattan, L. (2015). Conservation Effects on Soil Quality and Climate Change Adaptability of Ethiopian Watersheds. Land Degrad. Develop. 27: 1603-1621.

De Souza Braz AM, Fernandes A, Alleoni LRF. 2013. Soil attributes after the conversion from forest to pasture in Amazon. Land Degradation and Development 24: 33-38. DOI: 10.1002.ldr.1100.

Eshetu, A., Tadele, G., Gemechu, A., Desalegn, M., Alemayhu, D. 2016a. Effects of Level Fanya Juu and Fanya Chin Structures on Grain Yield of Maize in Moisture Stress Areas of Daro Labu District, West Hararghe Zone, Ethiopia. Journal of Biology, Agriculture and Healthcare. 6(21).

Eshetu, Ararso., Gemechu, Ayele., Tadele, Geremu. 2016b. Evaluation of Level Bund Conservation Structure for Maize and Sorghum Production in Moisture Deficit Areas of Hawi Gudina District, Eastern Ethiopia. Journal of Environment and Earth Science, 6(12).

Esser, K., Vagen, T., Yibabe, T., Mitiku, H. 2002. Soil Conservation in Tigray, Ethiopia: Noragric Report No. 5. Noragric Aas Norway.

FAO. 2005. The Importance of soil organic matter. Key to drought-resistant soil and sustained food and production. Rome.

Gebermichael, D., Nyssen, J., Poesen, J., Deckers, J., Haile, M., Govers, G., Moeyersons, J. 2005. Effectiveness of stone bunds in controlling soil erosion on cropland in the Tigray highlands, northern Ethiopia. Soil Use and Management. 21(3):287-297.

Girmay, G., Singh, BR., Mitiku, H., Borresen, T., Lal, R. 2008. Carbon stocks in Ethiopian soils in relation to land use and soil management. Land Degradation and Development 19: 351-367. DOI: 10.1002:1dr.844.

Haile, GW., Fetene, M. 2012. Assessment of soil erosion hazard in Kilie catchment, East Shoa, Ethiopia. Land Degradation and Development, 23: 293-306. DOI: 10.1002:1dr.1082.

Haregeweyn, N., Poesen, J., Verstraeten, G., Govers, G., de Vente, J., Nyssen, J., Deckers, J., Moeyersons, J. 2013. Assessing the performance of a spatially distributed soil erosion and sediment delivery model (WATEM/SEDEM) in Northern Ethiopia. Land Degradation \& Development 24: 188-204. DOI: 10.1002:ldr.1121.

Hurni, H. 1993. Land degradation, famine, and land resource scenarios in Ethiopia. In World soil erosion and conservation, Pimentel D (ed.).Cambridge University Press: Cambridge; 27-62.

Hurni, H., Bantider, A., Herweg, K., Portner, B., Veit, H. 2007. Landscape transformation and sustainable development in Ethiopia. Background information for a study tour through Ethiopia, September 4-20, 2006, CDE (Center for Development and Environment) University of Bern, Bern.

Jobbagy, E and Jackson, R. 2000. The Vertical Distribution of Soil Organic Carbon and Its Relation to Climate and Vegetation. Ecological Applications 10:423-436.

Karltun, E., Lemenih, M., Tolera, M. 2013. Comparing farmers' perception of soil fertility change with soil properties and crop performance in Beseku, Ethiopia. Land Degradation \& Development 24: 228-235. DOI: 10.1002:ldr.1118.

Kebede, W., Awdenegest, M., and Fantaw, Y. 2011.Effects of level soil bunds and stone bunds on soil properties and its implications for crop production: the case of Bokole watershed, Dawuro zone, Southern Ethiopia. Agricultural Sciences, 2(3): 357-363. Doi: 10.4236.as.2011.23047.

Kumar, P., Murkute, A., Gupta, S and Singh, S. 2009. Carbon Sequestration with Special Reference to Agroforestry in Cold Deserts of Ladakh, India.

Kurgat, B, K., Golicha, D., Giese, M., Kuria, S, G., and Asch, F. 2011. Relationship between vegetation cover types and soil organic carbon in the rangelands of Northern Kenya. Germany; Hohenheim University. OPenURL.

Lal, R. 2001. Potential of desertification control to sequester carbon and mitigate the greenhouse effect. Climate 
Change 15: 35-72.

Lal, R., Follett, RF., Kimble JM. 2003 Achieving soil carbon sequestration in the United States: a challenge to the policy makers. Soil Science. 168: 827-845. DOI: 10.1097:01.ss.0000106407.84926.6b.

Lal, R. 2004. Soil carbon sequestration to mitigate climate change. Geoderma 123: 1-22.

Lal, R. (2015). Restoring soil quality to mitigate soil degradation. Sustainable, 7(5), 5875-5895.

Lal, R. (2008). Carbon sequestration. Philosophical transactions of the royal society B; Biological Science, 363 (1492): 815-830.

Lal, R. 2009. Agriculture and Climate Change: An Agenda for Negotiation in Copenhagen For Food, Agriculture, and the Environment. The Potential for Soil Carbon Sequestration International Food Policy Research Institute, USA.

Lemma, T., Menfes, T., Fantaw, Y. 2015. Effects of integrating different soil and water conservation measures into hillside area closure on selected soil properties in Hawassa Zuria District, Ethiopia. Journal of Soil Science and Environmental Management. 6(10):268-274. DOI 10.5897:JSSEM15.0513.

Loveland, P., Webb, J. 2003. Is there a critical level of organic matter in the agricultural soils of temperate regions: A review. Soil and Tillage Research, 70(1):1-18.

Mekuria, A., Vlek, PL., Denich, GM. 2012. Application of the caesium-137 technique to soil degradation studies in the southwestern highlands of Ethiopia. Land Degradation \& Development 23: 456-464. DOI: 10.1002:ldr.1088.

Meshesha, DT., Tsunekawa, A., MM, Tsubo. 2012. Continuing land degradation: cause-effect in Ethiopia's Central Rift Valley. Land Degradation and Development 23: 130-143. DOI: 10.1002:1dr.1061.

Mighall TM, Foster IDL, Rowntree KM, Boardman J. 2012. Reconstructing recent land degradation in the semiarid Karoo of South Africa: a palaeoecological study at Compassberg, Eastern Cape. Land Degradation \& Development 23: 523-533. DOI: 10.1002/ldr.2176.

Morgan, R.P.C. 2005. Soil erosion and conservation. 3rd Edition. Blackwell Science Ltd, Oxford.

Oldeman, LR., Hakkeling, RTA., Sombroek, WG. 1991. World map of the status of human-induced soil degradation: an explanatory note. ISRIC: Wageningen.

Oxfam international. 2010. The rain doesn't come on time anymore. Poverty, vulnerability, and climate variability in Ethiopia. Oxfam International Research Report.

Pimentel, D., Harvey, C., Resosudarmo, P., Sinclair, K., Kurz, D., McNair, M., Crist, S., Shpritz, L., Fitton, L., Saffouri, R., Blair, R. 1995. Environmental and economic costs of soil erosion and conservation benefits Science. 267(5201):1117-1123.

Shiferaw, B., Holden, ST. 1999. Soil erosion and smallholders' conservation decisions in the highlands of Ethiopia. World Development, 27(4):739-752.

Sonneveld, BGJS. 2002. Land under pressure: the impact of water erosion on food production in Ethiopia. Shaker Publishing: Maastricht.

Solomon, T. 2015. On-Farm Verification of the Effects of Selected Soil Moisture Conservation Techniques on Yield and Yield Components of Early Maturing Maize Varieties at Bako, Western Ethiopia. International Journal of Advanced Earth Science and Engineering. 4(1): 254-264.

Stavins, R and Richards, K. 2005. The cost of U.S. forest-based carbon sequestration. Prepared for the Few Center on Global Climate Change, USA.

Tadele, A., Aemro, T., Yihenew, G.S., Birru, Y., Bettina, W., Hurni, H. 2013. Soil Properties and Crop Yields along the Terraces and Toposequence of Anjeni Watershed. Journal of Agricultural Science. 5(2).

Tadele, Geremu., Eshetu, Ararso., Desalegn, Mamo., Gemechu, Ayela., Alemayhu, Diriba., Bayisa Muleta., Dulo, Hussen. 2015. Effects of Negarim and Semi-circular Structures on Growth and Yield of Banana in Moisture Deficit Area of Daro Labu District, West Hararghe Zone, Ethiopia. Journal of Horticulture and Forestry, 8(4): 32-36.

Tekle, Y and Wedajo, G. 2015. Evaluation of different moisture conservation practices on growth, yield and yield components of sorghum at Alduba, southern Ethiopia. Research Journal of Agriculture and Environmental Management. 4(3): 169-173.

Tamrat, S., Endalikachew, K., Abebayehu, A. 2018. The effects of biological soil conservation practices and community perception toward these practices in the Lemo District of Southern Ethiopia. International Soil and Water Conservation Research. 123-130.

TerrAfrica. 2009. The role of sustainable land management (SLM) for climate change adaptation and mitigation in Sub-Saharan Africa (SSA). TerrAfrica Annual Report 2009.

Vagen, TG., Lal, R., Singh, BR. 2005. Soil carbon sequestration in Sub- Saharan Africa: a review. Land Degradation \& Development 16: 53-71. DOI: 10.1002:1dr.644.

Van Oost, K., Quine, T, A., Govers, De Gryze, S., Six, J., Harden, J,W., and Giraldez, J, V. 2007. The impact of agricultural soil erosion on the global carbon cycle. Science, 318 (5850), 626-629.

Wang, T., Yan, CZ., Song, X., Li, S. 2013. Landsat images reveal trends in the aeolian desertification in a source 
area for sand and dust storms in China's Alashan plateau (1975-2007). Land Degradation \& Development, 24: 422-429. DOI: 10.1002:ldr.1138.

Worku, H., Awdenegest, M., and Fantaw, Y. 2012. The Effects of 'Fanya juu' Soil Conservation Structure on Selected Soil Physical \& Chemical Properties: the Case of Goromti Watershed, Western Ethiopia. Resources and Environment, 2(4): 132-140. DOI: 10.5923:j.re.20120204.02.

Worku Hailu. 2017. Impact of Physical Soil and Water Conservation Structure on Selected Soil Physicochemical Properties in Gondar Zuriya Woreda. Resources and Environment, 7(2): 40-48. DOI: 10.5923:j.re.20170702.02.

World Bank .2010. Economics of adaptation to Climate Change, Ethiopia. World Bank Group 1818 H Street, NW Washington, DC 20433.

Yihenew, G.S., Fentanesh, A., and Solomon, A. 2015. Effect of Land Use Types, Management Practices and Slope Classes on Selected Soil Physico Chemical Properties in Zikre Watershed, North Western Ethiopia. Environmental System Research. DOI 10.1186:s40068-015-0027-0.

Yonas, A., Temesgen, K., Alemayehu, M and Toyiba, S. 2017. Evaluation of the effectiveness of soil and water conservation practices on improving selected soil properties in Wonago district, Southern Ethiopia. Journal of Soil Science and Environmental Management. 8(3), 70-79. DOI: 10.5897/JSSEM2016.0601.

Zougmore, R., Gnankambary, Z., Guillobez, S. and Stroosnijder, L. 2002. Effects of stone lines on soil che- mical characteristics under continuous sorghum cropping in semiarid Burkina Faso. Soil and Tillage Research, 66, 47-53. Doi:10.1016:S0167 1987(02)00012-0

Zougmoré, R., Mando, A., and Stroosnijder, L. 2009. Soil nutrient and sediment loss as affected by erosion barriers and nutrient source in Semi-Arid Burkina Faso. Arid Land Research and Management, 23, 85-101.

APPENDIX

Appendix Table 1. Effect of planting method and mulching rate of sorghum yield, Tigray region

\begin{tabular}{cccc}
\hline Treatments & $\begin{array}{c}\text { Grain yield } \\
(\mathrm{kg} / \mathrm{ha})\end{array}$ & $\begin{array}{c}\text { Stover yield } \\
(\mathrm{kg} / \mathrm{ha})\end{array}$ & Harvest index \\
\hline Plating methods & & & \\
FP & 1128 & 1987 & 0.26 \\
RU & 1511 & 2907 & 0.28 \\
FU & 2162 & 3969 & 0.31 \\
RT & 1683 & 3366 & 0.28 \\
FT & 2312 & 5365 & 0.31 \\
SEM+ & 91 & 158 & 0.11 \\
LSD (P $<0.05)$ & 264 & 458 & 0.32 \\
\hline Mulching Rate (t/ha) & & & \\
0 & 1551 & 2755 & 0.29 \\
3 & 1775 & 3632 & 0.28 \\
6 & 1952 & 3689 & 0.29 \\
SEM+ & 71 & 122 & 0.01 \\
LSD (P $<0.05)$ & 205 & 355 & Ns \\
CV\% & 16 & 14 & 11.5 \\
\hline
\end{tabular}

Flat planting (FP), Ridge planting on untied ridges (RU), Furrow planting between untied ridges (FU), Ridge planting on tied ridges (RT) and Furrow planting between tied ridges (FT) 
Appendix Table 2. Effect of Fanya Juu and Fanya chin on yield and yield components of maize, Western Hararghe zone, Daro Labu district

\begin{tabular}{|l|l|l|l|l|l|}
\hline \multirow{2}{*}{ Treatment } & \multicolumn{5}{|l|}{ Mean values of parameters during 2011 cropping season } \\
\cline { 2 - 6 } & STCH & NCpt & Yield (Qt/ha) & Days maturity & Yield advantage (\%) \\
\hline Level Fanya Juu & 572 & 661 & 52.7 & 112.00 & 7.5 \\
\hline Level Fanya Chin & 594 & 657 & 59.2 & 111.00 & 20.8 \\
\hline Control & 649 & 658 & 49 & 111.00 & \\
\hline Mean & $\mathbf{6 0 5}$ & $\mathbf{6 5 8 . 1}$ & $\mathbf{5 3 . 6 4}$ & 111.77 & \\
\hline LSD 0.05 & 175.3 & 118.25 & 5.1529 & 2.2031 & \\
\hline CV $(\%)$ & 12.78 & 7.92 & 4.270345 & 0.869 & \\
\hline
\end{tabular}

Table 2: Mean yield of maize variety (quintal ha-1), stand count at harvest (STCH) \& number of cobs per plot (NCpt) during 2012 cropping season

\begin{tabular}{|l|l|l|l|l|l|}
\hline \multirow{2}{*}{ Treatment } & \multicolumn{6}{|l|}{ Mean values of parameters during 2012 cropping season } \\
\cline { 2 - 6 } & STCH & NCpt & Yield (Qt/ha) & Days to maturity & Yield advantage (\%) \\
\hline Level Fanya Juu & 665 & 655 & 54.09 & 115 & 87 \\
\hline Level Fanya Chin & 709 & 694 & 41.9 & 115 & 45 \\
\hline Control & 357 & 343 & 28.9 & 113 & \\
\hline Mean & $\mathbf{5 7 7}$ & $\mathbf{5 6 4}$ & $\mathbf{4 1 . 6 4}$ & 114.222 & \\
\hline LSD 0.05 & 169.03 & 127.6 & 26.93 & 1.7722 & \\
\hline CV (\%) & 12.9 & 9.9 & 28.5 & 0.684 & \\
\hline
\end{tabular}

Appendix Table 3. Effect of soil bund on yield and yield component of maize and sorghum, Western Hararghe zone, Hawi Gudina district

\begin{tabular}{|c|c|c|c|c|}
\hline \multirow[t]{4}{*}{ Parameters collected } & \multicolumn{4}{|c|}{ Types of field crop used } \\
\hline & \multicolumn{2}{|c|}{ Maize (Melkasa-4) } & \multicolumn{2}{|c|}{ Sorghum (Abshir) } \\
\hline & \multicolumn{4}{|c|}{ Conservation structure } \\
\hline & Level Bund & Farmers practice & Level Bund & Farmers practice \\
\hline Stand count at Harvest/ha & 15,300 & 16,800 & 58,000 & 50,800 \\
\hline No. Cobs (heads)/ha & 11,000 & 11,100 & 56,300 & 47,900 \\
\hline Days to maturity & 115 & 112 & 120 & 119 \\
\hline Yield (Qt/ha) & 8.5 & 6.7 & 23.5 & 15.32 \\
\hline Yield advantage $(\%)$ & 26.8 & - & 53.3 & - \\
\hline
\end{tabular}


Appendix Table 4. Effect of fanya juu on soil physico chemical properties, Ambo district, Goromti watershed

\begin{tabular}{|c|c|c|c|c|c|}
\hline \multirow{2}{*}{ Variable } & \multirow{2}{*}{ Slope gradient } & \multicolumn{4}{|c|}{ Conservation practice } \\
\hline & & Control & F juu 5 & F juu 10 & Over all \\
\hline \multirow{5}{*}{ SOC (\%) } & $3-15$ & $2.24 \pm 0.18$ & $2.38 \pm 0.08$ & $2.37 \pm 0.05$ & $2.35 \pm 0.06 a$ \\
\hline & $15-30$ & $1.94 \pm 0.09$ & $2.31 \pm 0.06$ & $2.18 \pm 0.07$ & $2.15 \pm 0.07 \mathrm{a}$ \\
\hline & $>30$ & $1.68 \pm 0.07$ & $1.92 \pm 0.03$ & $1.94 \pm 0.24$ & $1.86 \pm 0.08 b$ \\
\hline & Over all & $1.96 \pm 0.10 \mathrm{~b}$ & $2.21 \pm 0.08 a$ & $2.17 \pm 0.1 \mathrm{ab}$ & \\
\hline & $3-15$ & $0.19 \pm 0.019$ & $0.24 \pm 0.03$ & $0.28 \pm 0.05$ & $0.24 \pm 0.02 \mathrm{a}$ \\
\hline \multirow{2}{*}{$\mathrm{N}(\%)$} & $15-30$ & $0.16 \pm 0.024$ & $0.20 \pm 0.05$ & $0.19 \pm 0.04$ & $0.20 \pm 0.01 \mathrm{ab}$ \\
\hline & $>30$ & $0.17 \pm 0.04$ & $0.19 \pm 0.02$ & $0.24 \pm 0.07$ & $0.18=0.02 b$ \\
\hline \multirow{5}{*}{$\mathrm{C}: \mathrm{N}(\%)$} & Over all & $0.17 \pm 0.009 b$ & $0.21 \pm 0.0 .01 \mathrm{ab}$ & $0.24 \pm 0.01 \mathrm{a}$ & \\
\hline & $3-15$ & $11.86 \pm 0.41$ & $10.06 \pm 0.56$ & $8.43 \pm 0.70$ & $10.11 \pm 0.57 \mathrm{ab}$ \\
\hline & $15-30$ & $11.92 \pm 0.69$ & $12.05 \pm 1.57$ & $11.46 \pm 1.06$ & $11.81 \pm 0.59 \mathrm{a}$ \\
\hline & $>30$ & $10.49 \pm 2.22$ & $9.56 \pm 0.46$ & $8.16 \pm 0.98$ & $9.44 \pm 0.79 \mathrm{~b}$ \\
\hline & Over all & $11.42 \pm 0.72 \mathrm{a}$ & $10.58 \pm 0.62 \mathrm{a}$ & $9.35 \pm 0.70 \mathrm{a}$ & \\
\hline \multirow[t]{2}{*}{ Variable } & Slope gradi- & \multicolumn{4}{|c|}{ Conservation practice } \\
\hline & ent & Control & F juu 5 & $F_{\text {juu }} 10$ & Over all \\
\hline \multirow{3}{*}{$\mathrm{pH}$} & $3-15$ & $5.71 \pm 0.063$ & $5.80 \pm 0.038$ & $5.80 \pm 0.115$ & $5.77 \pm 0.04 a$ \\
\hline & $15-30$ & $5.41 \pm 0.072$ & $5.25 \pm 0.112$ & $5.79 \pm 0.043$ & $5.48 \pm 0.08 b$ \\
\hline & $>30$ & $5.57 \pm 0.052$ & $5.42 \pm 0.072$ & $5.67 \pm 0.040$ & $5.55 \pm 0.04 b$ \\
\hline \multirow{4}{*}{$\mathrm{EC}(\mathrm{ms} / \mathrm{cm})$} & Over all & $5.56 \pm 0.05 b$ & $5.49 \pm 0.09 b$ & $5.75 \pm 0.04 a$ & \\
\hline & $3-15$ & $0.07 \pm 0.003$ & $0.05 \pm 0.003$ & $0.07 \pm 0.003$ & $0.061 \pm .004 \mathrm{ab}$ \\
\hline & $15-30$ & $0.05 \pm 0.008$ & $0.05 \pm 0.003$ & $0.06 \pm 0.00$ & $0.05 \pm 0.003 b$ \\
\hline & $>30$ & $0.07 \pm 0.006$ & $0.07 \pm 0.01$ & $0.06 \pm 0.001$ & $0.06 \pm 0.004 a$ \\
\hline \multirow{5}{*}{ CEC (cmolc/kg) } & Over all & $0.062 \pm 0.005 a$ & $0.056 \pm 0.004 a$ & $0.062 \pm 0.002 \mathrm{a}$ & \\
\hline & $3-15$ & $33.89 \pm 2.61$ & $37.12 \pm 4.15$ & $33.30 \pm 2.17$ & $34.77 \pm 1.66 a$ \\
\hline & $15-30$ & $31.21 \pm 2.01$ & $31.04 \pm 2.98$ & $30.38 \pm 1.35$ & $30.88 \pm 1.12 a$ \\
\hline & $>30$ & $29.97 \pm 2.44$ & $30.66 \pm 1.48$ & $28.65 \pm 1.78$ & $29.77 \pm 1.02 \mathrm{a}$ \\
\hline & Over all & $31.69 \pm 1.32 \mathrm{a}$ & $32.95 \pm 1.86 a$ & $30.78 \pm 1.13 \mathrm{a}$ & \\
\hline \multirow{4}{*}{$\mathrm{Av} \_\mathrm{p}(\mathrm{gm})$} & $3-15$ & $28.48 \pm 10.69$ & $18.27 \pm 4.28$ & $16.81 \pm 2.62$ & $25.10 \pm 4.81 \mathrm{a}$ \\
\hline & $15-30$ & $29.35 \pm 8.84$ & $31.37 \pm 16.20$ & $22.84 \pm 5.47$ & $27.85 \pm 5.70 a$ \\
\hline & $>30$ & $17.20 \pm 4.77$ & $20.74 \pm 1.32$ & $45.31 \pm 13.97$ & $23.84 \pm 5.67 \mathrm{a}$ \\
\hline & Over all & $25.01 \pm 4.67 \mathrm{a}$ & $23.47 \pm 5.25 \mathrm{a}$ & $28.33 \pm 6.17 \mathrm{a}$ & \\
\hline \multirow{4}{*}{ Av_K (gm) } & $3-15$ & $1087.70 \pm 391$ & $553.8 \pm 56.47$ & $753.5 \pm 34.4$ & $798.35 \pm 138.64 a$ \\
\hline & $15-30$ & $914.19 \pm 206.2$ & $786.9 \pm 63.1$ & $616.5 \pm 11.5$ & $772.57 \pm 75.81 \mathrm{a}$ \\
\hline & $>30$ & $1057.2 \pm 302.9$ & $1297.7 \pm 35.6$ & $938.3 \pm 84.6$ & $1097.7 \pm 105.58 \mathrm{a}$ \\
\hline & Over all & $564.08 \pm 21.72$ & $540.06 \pm 32.72$ & $618.36 \pm 34.14$ & \\
\hline \multirow{2}{*}{ Variable } & \multirow{2}{*}{$\begin{array}{l}\text { Slope } \\
\text { gradient }\end{array}$} & \multicolumn{4}{|c|}{ Conservation practice } \\
\hline & & Control & F juu 5 & F juu 10 & Over all \\
\hline \multirow{4}{*}{$\mathrm{Na}(\mathrm{cmolc} / \mathrm{kg}$} & $3-15$ & $0.46 \pm 0.07$ & $0.21 \pm 0.04$ & $0.23 \pm 0.02$ & $0.30 \pm 0.05 a$ \\
\hline & $15-30$ & $0.48 \pm 0.10$ & $0.240 \pm .05$ & $0.38 \pm 0.04$ & $0.36 \pm 0.05 a$ \\
\hline & $>30$ & $0.53 \pm 0.18$ & $0.49 \pm 0.02$ & 0.350 .03 & $0.46 \pm 0.06 a$ \\
\hline & Over all & $0.49 \pm 0.06 \mathrm{a}$ & $0.32 \pm 0.05 b$ & $0.32 \pm 0.03 b$ & \\
\hline \multirow{4}{*}{$\mathrm{K}(\mathrm{cmolc} / \mathrm{kg})$} & $3-15$ & $3.25 \pm 0.75$ & $1.46 \pm 0.19$ & $1.54 \pm 0.06$ & $2.09 \pm 0.37 \mathrm{a}$ \\
\hline & $15-30$ & $2.22 \pm 0.16$ & $1.70 \pm 0.15$ & $2.07 \pm 0.17$ & $2.001 \pm 0.11 \mathrm{a}$ \\
\hline & $>30$ & $2.83 \pm 0.95$ & $2.89 \pm 0.08$ & $2.19 \pm 0.11$ & $2.64 \pm 0.30 \mathrm{a}$ \\
\hline & Over all & $2.77 \pm 0.38 \mathrm{a}$ & $2.02 \pm 0.23 \mathrm{a}$ & $1.94 \pm 0.12 \mathrm{a}$ & \\
\hline \multirow{4}{*}{$\mathrm{Ca}(\mathrm{cmolc} / \mathrm{kg})$} & $3-15$ & $12.60 \pm 2.43$ & $13.65 \pm 1.55$ & $14.46 \pm 2.08$ & $13.57 \pm 1.06 \mathrm{a}$ \\
\hline & $15-30$ & $11.83 \pm 0.32$ & $11.25 \pm 1.32$ & $15.27 \pm 2.02$ & $12.79 \pm 0.94 a$ \\
\hline & $>30$ & $12.56 \pm 1.52$ & $13.89 \pm 1.81$ & $15.55 \pm 0.50$ & $14.01 \pm 0.82 \mathrm{a}$ \\
\hline & Over all & $12.33 \pm 0.84 a$ & $12.94 \pm 0.89 a$ & $15.1 \pm 0.87 a$ & \\
\hline & $3-15$ & $7.40 \pm 2.66$ & $10.69 \pm 2.11$ & $13.02 \pm 2.28$ & $10.37 \pm 1.44 a$ \\
\hline $\mathrm{M} \sigma(\mathrm{cmolc} / \mathrm{kg})$ & $15-30$ & $8.65 \pm 1.01$ & $10.37 \pm 3.59$ & $10.95 \pm 1.88$ & $9.10 \pm 1.25 a$ \\
\hline Nig( Cmole/kg) & $>30$ & $6.59 \pm 1.57$ & $5.19 \pm 2.15$ & $11.23 \pm 0.86$ & $7.01 \pm 1.22 \mathrm{a}$ \\
\hline & Over all & $7.55 \pm 0.99 \mathrm{a}$ & $8.75 \pm 1.62 \mathrm{a}$ & $11.73 \pm 0.95 \mathrm{a}$ & \\
\hline
\end{tabular}

Note:- Means within rows followed by different letters are significantly different $(p<0.05)$ with respect to treatment and slope gradient. 
Appendix Table 5. Effect of level soil bund and stone bund on soil physico chemical properties, Bokole watershed

\begin{tabular}{|c|c|c|c|c|c|c|c|c|c|c|c|}
\hline Soil texture & \multicolumn{2}{|c|}{ LSB-4 year } & \multicolumn{2}{|c|}{ NTU-1 } & $P$-value & LSB-6 year & NTU-2 & $P$-value & LSB-9 year & NTU-3 & $P$-value \\
\hline Sand (\%) & \multicolumn{2}{|c|}{$47.17 \pm 0.75$} & \multicolumn{2}{|c|}{$4383 \pm 189$} & & & & \multirow{2}{*}{$\begin{array}{c}0.785 \\
0.011^{*}\end{array}$} & $46.00 \pm 2.7$ & \multirow{2}{*}{$\begin{array}{c}47.8 \pm 3.00 \\
18.17 \pm 0.98\end{array}$} & \multirow{2}{*}{$\begin{array}{l}0.659 \\
0.908\end{array}$} \\
\hline Silt (\%) & \multicolumn{2}{|c|}{$17.17 \pm 0.60$} & \multicolumn{2}{|c|}{$18.67 \pm 0.80$} & $\begin{array}{l}0.132 \\
0.166\end{array}$ & $\begin{array}{l}47.17 \pm 1.76 \\
25.67 \pm 1.80\end{array}$ & $\begin{array}{c}47.83 \pm 1.6 \\
19.33+0.95\end{array}$ & & $18.00=1.00$ & & \\
\hline Clay (\%) & \multicolumn{2}{|c|}{$35.67 \pm 0.56$} & \multicolumn{2}{|c|}{$37.50 \pm 1.31$} & 0.227 & $27.17 \pm 1.45$ & $32.83 \pm 1.72$ & $0.030^{*}$ & $36.00 \pm 2.58$ & \multirow{2}{*}{$\begin{array}{c}34.00 \pm 2.13 \\
\text { Sandy } \\
\text { clay loam }\end{array}$} & \multirow[t]{2}{*}{0.563} \\
\hline Textural Classes & Sand & y clay & Clay & y loam & & $\begin{array}{c}\text { Sandy clay } \\
\text { loam }\end{array}$ & andy clay loam & & Sandy clay & & \\
\hline \multicolumn{12}{|c|}{ *denotes significantly different values from each other at $P<0.05$ by 2 -tailed t-test } \\
\hline Soil texture & \multicolumn{2}{|c|}{ SB-4 year } & & NTL-1 & $P$-value & SB-6 year & NTL- 2 & $P$-value & SB- 8 year & NTL- 3 & $P$-value \\
\hline Sand (\%) & & $67 \pm 1.31$ & & $99.67 \pm 1.43$ & 0.066 & $49.17 \pm 1.40$ & $53.50 \pm 1.63$ & 0.071 & $48.67 \pm 2.12$ & $47.83 \pm 1.64$ & 0.763 \\
\hline Silt (\%) & & $00 \pm 1.39$ & & $16.83 \pm 0.60$ & 0.091 & $20.33 \pm 0.67$ & $17.33 \pm 0.95$ & $0.028^{*}$ & 23.67 & $23.33 \pm 1.20$ & 0.871 \\
\hline Clay (\%) & & $33 \pm 1.10$ & & $23.50 \pm 1.34$ & $0.003^{*}$ & $30.5 \pm 1.18$ & $29.17 \pm 1.51$ & 0.503 & $27.67 \pm 0.95$ & $28.83 \pm 1.05$ & 0.429 \\
\hline Textural Classe: & Sand & y clay lo? & $\mathrm{am} \mathrm{Sar}$ & ndy clay loam & & $\begin{array}{c}\text { Sandy clay } \\
\text { loam }\end{array}$ & $\begin{array}{c}\text { Sandy clay } \\
\text { loam }\end{array}$ & & $\begin{array}{c}\text { Sandy clay } \\
\text { loam }\end{array}$ & Sandy clay loam & \\
\hline notes signifi & diffi & . & (1) fr & ach other & $P<0.05$ by & by 2-tailed t-test & & & & & \\
\hline Soil paramet & & LSB-4 & year & NTU-1 & $P$-value & LSB-6 year & NTU-2 & $P$-value & LSB-9 year & NTU-3 & $P$-value \\
\hline SOC (\%) & & $1.23 \pm$ & 0.15 & $1.32 \pm 0.23$ & 0.736 & $1.41 \pm 0.28$ & $1.18 \pm 0.11$ & 0.463 & $1.57 \pm 0.27$ & $1.68 \pm 0.15$ & 0.715 \\
\hline $\mathrm{TN}(\%)$ & & $0.11 \pm$ & 0.02 & $0.07 \pm 0.02$ & 0.275 & $0.21 \pm 0.13$ & $0.12 \pm 0.04$ & 0.515 & $0.08 \pm 0.02$ & $0.17 \pm 0.06$ & 0.138 \\
\hline $\mathrm{AP}(\mathrm{ppm})$ & & $12.04=$ & $=0.56$ & $16.87 \pm 1.94$ & $4 \quad 0.037^{*}$ & $5.86 \pm 0.95$ & $3.94 \pm 1.66$ & 0.131 & $10.5 \pm 2.70$ & $5.68 \pm 0.39$ & 0.105 \\
\hline $\mathrm{AK} \mathrm{cmol}(+) / \mathrm{kg}$ & soil) & $0.15 \pm$ & 0.003 & $0.21 \pm 0.04$ & 0.138 & $0.23 \pm 0.06$ & $0.31 \pm 0.13$ & 0.600 & $0.20 \pm 0.06$ & $0.14 \pm 0.004$ & 0.326 \\
\hline $\begin{array}{c}\mathrm{pH} \\
\mathrm{CEC} \mathrm{cmol}(+) / \mathrm{k}\end{array}$ & g soil) & $\begin{array}{r}5.26 \pm \\
20.57=\end{array}$ & $\begin{array}{l}0.15 \\
=2.63\end{array}$ & $\begin{array}{r}5.64 \pm 0.04 \\
29.75 \pm 3.48\end{array}$ & $\begin{array}{cc}t & 0.034^{*} \\
8 & 0.062\end{array}$ & $\begin{array}{c}5.87 \pm 0.10 \\
17.16 \pm 2.10\end{array}$ & $\begin{array}{c}5.34 \pm 0.23 \\
0 \quad 21.27 \pm 4.03\end{array}$ & $\begin{array}{l}0.068 \\
0.380\end{array}$ & $\begin{array}{c}5.83 \pm 0.07 \\
16.75 \pm 1.57\end{array}$ & $\begin{array}{c}5.93 \pm 0.08 \\
18.33 \pm 1.53\end{array}$ & $\begin{array}{l}0.383 \\
0.487\end{array}$ \\
\hline
\end{tabular}

*denotes significantly different values from each other at $P<0.05$ by 2 -tailed t-test

\begin{tabular}{|c|c|c|c|c|c|c|c|c|c|}
\hline Soil parameters & SB-4 year & NTL- 1 & $P$-value & SB-6 year & NTL-2 & $P$-value & SB-8 year & NTL-3 & $P$-value \\
\hline SOC (\%) & $1.57 \pm 0.16$ & $1.22 \pm 0.12$ & 0.101 & $1.35 \pm 0.14$ & $1.10 \pm 0.12$ & 0.206 & $0.69 \pm 0.11$ & $1.01 \pm 0.09$ & $0.048 *$ \\
\hline $\mathrm{TN}(\%)$ & $0.28 \pm 0.08$ & $0.13 \pm 0.03$ & 0.098 & $0.09 \pm 0.06$ & $0.06 \pm 0.02$ & 0.619 & $0.41 \pm 0.13$ & $0.26 \pm 0.12$ & 0.409 \\
\hline $\mathrm{AP}(\mathrm{ppm})$ & $2.92 \pm 0.65$ & $4.41 \pm 0.46$ & 0.089 & $1.82 \pm 0.13$ & $7.33 \pm 1.74$ & $0.010^{*}$ & $10.62 \pm 1.71$ & $27.48 \pm 6.20$ & $0.026^{*}$ \\
\hline $\mathrm{AK} \mathrm{cmol}(+) / \mathrm{kg}$ soil) & $0.45 \pm 0.08$ & $0.44 \pm 0.02$ & 0.906 & $1.39 \pm 0.30$ & $0.83=0.15$ & 0.123 & $0.59 \pm 0.29$ & $1.61 \pm 0.32$ & $0.039 *$ \\
\hline $\mathrm{pH}$ & $7.06 \pm 0.034$ & $7.13 \pm 0.02$ & 0.090 & $6.34 \pm 0.05$ & $6.63 \pm 0.087$ & $0.014^{*}$ & $6.41 \pm 0.08$ & $6.64 \pm 0.04$ & $0.03 *$ \\
\hline $\mathrm{CEC} \mathrm{cmol} \mathrm{(+)/kg} \mathrm{soil)}$ & $25.70 \pm 5.85$ & $21.80 \pm 5.19$ & 0.629 & $30.43 \pm 4.46$ & $31.43 \pm 3.52$ & 0.864 & $31.57 \pm 2.96$ & $25.93 \pm 6.85$ & 0.468 \\
\hline
\end{tabular}

*denotes significantly different values from each other at $P<0.05$ by 2 -tailed t-test

Appendix Table 6. Effect of Management practices on selected soil physico chemical properties Zikri watershed

\begin{tabular}{|c|c|c|c|c|c|c|}
\hline Management practices & $\mathrm{pH}\left(\mathrm{H}_{2} \mathrm{O}\right)$ & TN (\%) & AP $\left(\mathrm{mg} \mathrm{kg}^{-1}\right)$ & OM (\%) & CEC $\left(\mathrm{Cmol}_{(+)} \mathrm{kg}^{-1}\right)$ & $\operatorname{Bd}\left(\mathrm{g} \mathrm{cm}^{-3}\right)$ \\
\hline Manure and soil bund & $6.36^{2}$ & $0.29^{2}$ & $18.41^{2}$ & $5.88^{2}$ & $31.10^{2}$ & $1.14^{c}$ \\
\hline Bund & $5.72^{c}$ & $0.14^{c}$ & $4.91^{c}$ & 2.77 & $2926^{\mathrm{b}}$ & $1.26^{a b}$ \\
\hline Manure & $6.03^{b}$ & $0.21^{b}$ & $10.13^{b}$ & $4.50^{\circ}$ & $3080^{*}$ & $1.24^{b}$ \\
\hline No manure and no soil bund & $5.63^{c}$ & $0.14^{c}$ & $2.53^{c}$ & $2.63^{c}$ & $2502^{6}$ & $1.30^{2}$ \\
\hline
\end{tabular}

Means in a column followed by the same letter are not statistically different at $p \leq 0.05$.

Appendix Table 7. Effect of Soil Conservation Practices on basic soil properties, Lemo District of Southern Ethiopia

\begin{tabular}{|c|c|c|c|c|c|c|}
\hline \multirow[t]{2}{*}{ Soil parameters } & \multicolumn{2}{|c|}{ Lands treated with } & \multirow[t]{2}{*}{ Degraded grazing land } & \multirow[t]{2}{*}{$\mathrm{cV} \%$} & \multirow[t]{2}{*}{ LSD 5\% } & \multirow[t]{2}{*}{$\mathrm{P}$-value } \\
\hline & sesbania & elephant grass & & & & \\
\hline Clay (\%) & $49.0 \pm 3.46^{4}$ & $47.0 \pm 11.8^{4}$ & $31.5 \pm 1.9^{b}$ & 16.95 & 11.52 & 0.014 \\
\hline Silt $(x)$ & $28.5+5.26^{b}$ & $29.5+7.72^{b}$ & $41.0+1.15^{4}$ & 16.47 & 8.67 & 0.017 \\
\hline Sand $(x)$ & $22.5 \pm 3.0^{4}$ & $23.5 \pm 5.26^{4}$ & $27.5 \pm 1.91^{4}$ & 14.96 & 5.86 & 0.180 \\
\hline $\mathrm{BD}\left(\mathrm{g} / \mathrm{cm}^{3}\right)$ & $1.08 \pm 0.12^{b}$ & $1.12 \pm 0.02^{b}$ & $1.26 \pm 0.04^{4}$ & 6.84 & 0.13 & 0.024 \\
\hline $\mathrm{pH} \mathrm{H}_{2} \mathrm{O}$ & $6.1 \pm 0.22^{4}$ & $6 \pm 0.29^{4 b}$ & $5.5 \pm 0.35^{b}$ & 5.05 & 0.47 & 0.043 \\
\hline $\mathrm{OC}(\mathrm{x})$ & $2.37 \pm 0.11^{4}$ & $2.17 \pm 0.03^{b}$ & $1.97 \pm 0.15^{c}$ & 5.19 & 0.18 & 0.002 \\
\hline $\mathrm{TN}(x)$ & $0.21 \pm 0.01^{4}$ & $0.185 \pm 0.0^{b}$ & $0.165 \pm 0.06$ & 5.05 & 0.01 & 0.000 \\
\hline Av. $\mathrm{P}(\mathrm{ppm})$ & $3.85 \pm 0.31^{4}$ & $3.52 \pm 0.46^{\circ}$ & $2.86 \pm 0.47^{\circ}$ & 12.31 & 0.67 & 0.025 \\
\hline $\mathrm{CEC}(\mathrm{meq} / 100 \mathrm{~g})$ & $32.68+1.7^{4}$ & $30.96 \pm 6.0^{4}$ & $22.55 \pm 1.07^{b}$ & 12.75 & 5.86 & 0.007 \\
\hline $\mathrm{Ca}^{2}+(\mathrm{meq} / 100 \mathrm{~g})$ & $25.48 \pm 1.33^{4}$ & $24.14 \pm 4.6^{4}$ & $17.58 \pm 0.8^{b}$ & 12.74 & 4.56 & 0.007 \\
\hline $\mathrm{Mg}^{2+}(\mathrm{meq} / 100 \mathrm{~g})$ & $3.39 \pm 0.17^{4}$ & $3.20 \pm 0.6^{4}$ & $2.33 \pm 0.11^{b}$ & 12.73 & 0.60 & 0.007 \\
\hline $\mathrm{K}^{+}(\mathrm{meq} / 100 \mathrm{~g})$ & $1.57 \pm 0.10^{4}$ & $1.41 \pm 0.18^{\circ}$ & $1.15 \pm 0.18^{b}$ & 11.94 & 0.26 & 0.015 \\
\hline $\mathrm{Na}^{+}(\mathrm{meq} / 100 \mathrm{~g})$ & $0.05 \pm 0.00^{4}$ & $0.042 \pm 0.00^{4}$ & $0.032 \pm 0.0^{3}$ & 14.9 & 0.01 & 0.010 \\
\hline
\end{tabular}

Means within rows followed by the same letters are not significantly different at $\mathrm{P}<.05$, CV $=$ Coefficient of variance. 
Appendix Table 8. Effect of moisture conservation on yield and yield components of maize, Western Oromia, Bako area

\begin{tabular}{|c|c|c|c|c|c|c|c|c|c|c|c|c|}
\hline Treatment & $\begin{array}{c}\text { GY } \\
\text { (kg/ha) }\end{array}$ & $\begin{array}{c}\text { AGB/G } \\
Y \\
\text { (t/ha) }\end{array}$ & $\begin{array}{l}\text { AEL } \\
(\mathrm{cm})\end{array}$ & $\begin{array}{l}\text { AEW } \\
(\mathrm{cm})\end{array}$ & ANL/pt & $\begin{array}{l}\text { MSD } \\
(\mathrm{cm})\end{array}$ & $\begin{array}{l}\text { MPHT } \\
\text { @50\%t } \\
\text { s (cm) }\end{array}$ & $\begin{array}{l}\% \mathrm{MC} \\
\text { day } 1 \\
(0-20)\end{array}$ & $\begin{array}{l}\% \mathrm{MC} \\
\text { day } 2 \\
(0-20)\end{array}$ & $\begin{array}{l}\% M C \\
\text { day } 3 \\
(0-20)\end{array}$ & $\begin{array}{l}\% M C \\
\text { day } 4 \\
(0-20)\end{array}$ & $\begin{array}{l}\% M C \\
\text { day } 5 \\
(0-20)\end{array}$ \\
\hline \multicolumn{13}{|c|}{ Variety } \\
\hline Local (V1) & $1097.89^{b}$ & $1.85^{\mathrm{a}}$ & $11.79^{\mathrm{a}}$ & $11.11^{\mathrm{c}}$ & $11.33^{\mathrm{a}}$ & $1.97^{\mathrm{a}}$ & $91.56^{b}$ & $54.11^{\text {ab }}$ & $31.22^{a}$ & $24.00^{b}$ & $24.11^{b}$ & $46.44^{\mathrm{b}}$ \\
\hline ACV3 (V2) & $1102.44^{\mathrm{b}}$ & $1.38^{\mathrm{b}}$ & $10.65^{c}$ & $12.07^{\mathrm{a}}$ & $10.33^{c}$ & $1.87^{\mathrm{b}}$ & $95.80^{b}$ & $48.89^{c}$ & $31.78^{\mathrm{a}}$ & $24.22^{\mathrm{b}}$ & $24.67^{\mathrm{b}}$ & $44.56^{\mathrm{b}}$ \\
\hline ACV4 (V3) & $1020.22^{c}$ & $1.34^{\mathrm{b}}$ & $11.15^{\mathrm{b}}$ & $12.35^{\mathrm{a}}$ & $10.78^{\mathrm{b}}$ & $1.89^{\mathrm{b}}$ & $104.56^{\mathrm{a}}$ & $55.78^{a}$ & $31.00^{\mathrm{a}}$ & $24.89^{\mathrm{a}}$ & $26.44^{\mathrm{a}}$ & $49.00^{\mathrm{a}}$ \\
\hline Katumani(V4) & $1236.89^{\mathrm{a}}$ & $1.94^{\mathrm{a}}$ & $10.46^{c}$ & $11.49^{b}$ & $11.22^{\mathrm{a}}$ & $1.90^{\mathrm{b}}$ & $94.78^{\mathrm{b}}$ & $51.11^{\mathrm{bc}}$ & $31.00^{\mathrm{a}}$ & $23.22^{\mathrm{C}}$ & $26.56^{\mathrm{a}}$ & $46.00^{\mathrm{b}}$ \\
\hline \multicolumn{13}{|c|}{ Water Conservation Technique } \\
\hline FBP & $853.17^{\mathrm{a}}$ & $1.29^{c}$ & $10.13^{c}$ & $11.40^{c}$ & $10.42^{b}$ & $1.81^{c}$ & $83.42^{b}$ & $45.50^{c}$ & $29.33^{c}$ & $23.42^{b}$ & $24.33^{c}$ & $41.42^{c}$ \\
\hline CPR & $873.25^{b}$ & $1.50^{\mathrm{b}}$ & $11.62^{\mathrm{a}}$ & $12.09^{\mathrm{a}}$ & $11.08^{a}$ & $2.00^{a}$ & $102.25^{\mathrm{a}}$ & $53.17^{\mathrm{b}}$ & $30.25^{\mathrm{b}}$ & $23.17^{\mathrm{b}}$ & $25.50^{\mathrm{b}}$ & $46.76^{b}$ \\
\hline CPF & $1616.67^{b}$ & $2.09^{\mathrm{a}}$ & $11.28^{\mathrm{b}}$ & $11.77^{\mathrm{b}}$ & $11.25^{\mathrm{a}}$ & $1.91^{\mathrm{b}}$ & $104.33^{\mathrm{a}}$ & $58.75^{\mathrm{a}}$ & $34.17^{\mathrm{a}}$ & $25.67^{\mathrm{a}}$ & $26.50^{\mathrm{a}}$ & $51.42^{\mathrm{a}}$ \\
\hline \multicolumn{13}{|c|}{ Significance } \\
\hline Variety & ** & ** & ** & 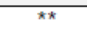 & ** & * & ** & ** & NS & ** & ** & ** \\
\hline Water conser. & ** & ** & ** & ** & ** & $* \star$ & ** & ** & ** & ** & ** & ** \\
\hline $\begin{array}{c}\text { VarietyXconser } \\
\text { vation }\end{array}$ & ** & ** & ** & NS & ** & * & NS & NS & * & ** & ** & * \\
\hline CV (\%) & 8.59 & 14.19 & 4.60 & 4.42 & 4.13 & 4.99 & 7.08 & 8.71 & 3.77 & 2.98 & 6.46 & 6.80 \\
\hline
\end{tabular}

$\% \mathrm{MC}$ day $1,2,3,4,5$, Indicate Gravimetric Moisture Content Values Measured at Different Dates in the Growing Season on Dry Soil Basis. GY: Grain Yield; AGBY/GY: Above Ground Biomass Yield Excluding Grain Yield; AEL: Average Maize Ear Length at Harvest; AEW: Average Maize Ear Width at Harvest; ANL/pt: Average Number of Leaves per Plant At $50 \%$

Tasseling; MSD: Maize Stalk Diameter at 50\% Tasseling; MPHT@50\%ts: Mean Plant Height at 50\% Tasseling

Appendix Table 9. Effect of graded stone bunds on selected soil properties, Central highland of Ethiopia

\begin{tabular}{|c|c|c|c|c|c|}
\hline \multirow{2}{*}{ Variables } & \multicolumn{3}{|c|}{ slope percentage } & \multicolumn{2}{|c|}{ conservation practices } \\
\hline & $15-20 \%$ & $20-25 \%$ & $\geq 25 \%$ & conserved & non conserved \\
\hline $\mathrm{BD}$ & $1.15 \pm 0.02 \mathrm{a}$ & $1.14 \pm 0.03 \mathrm{a}$ & $1.21 \pm 0.01 \mathrm{~b}$ & $1.13 \pm 0.02 \mathrm{a}$ & $1.21 \pm 0.03 b$ \\
\hline $\mathrm{MC}$ & $18.71 \pm 0.59 \mathrm{ab}$ & $19.76 \pm 0.95 \mathrm{a}$ & $17.22 \pm 0.51 b$ & $19.57 \pm 0.60 \mathrm{a}$ & $17.55 \pm 0.55 b$ \\
\hline $\mathrm{OM}$ & $3.49 \pm 0.13 \mathrm{a}$ & $3.24 \pm 0.14 b$ & $2.71 \pm 0.11 \mathrm{c}$ & $3.42 \pm 0.13 \mathrm{a}$ & $2.87 \pm 0.12 b$ \\
\hline TN & $0.25 \pm 0.03 a$ & $0.21 \pm 0.02 b$ & $0.16 \pm 0.01 \mathrm{c}$ & $0.24 \pm 0.02 \mathrm{a}$ & $0.17 \pm 0.01 b$ \\
\hline CEC & $36.08 \pm 1.14 a$ & $34.59 \pm 1.43 a$ & $31.78 \pm 1.16 \mathrm{~b}$ & $38.24 \pm 0.49 \mathrm{a}$ & $30.07 \pm 0.79 b$ \\
\hline $\mathrm{pH}$ & $5.57 \pm 0.06 \mathrm{a}$ & $5.56 \pm 0.05 a$ & $5.59 \pm 0.07 \mathrm{a}$ & $5.55 \pm 0.04 a$ & $5.61 \pm 0.06 \mathrm{a}$ \\
\hline
\end{tabular}

Means followed by the same letter(s) horizontally for each variable are not significantly different at $(\mathrm{p} \leq 0.05)$ with respect to treatments and slope gradients. 
Appendix Table 10. Effect of Conservation terraces on soil organic carbon storage and soil properties, Anjeni watershed

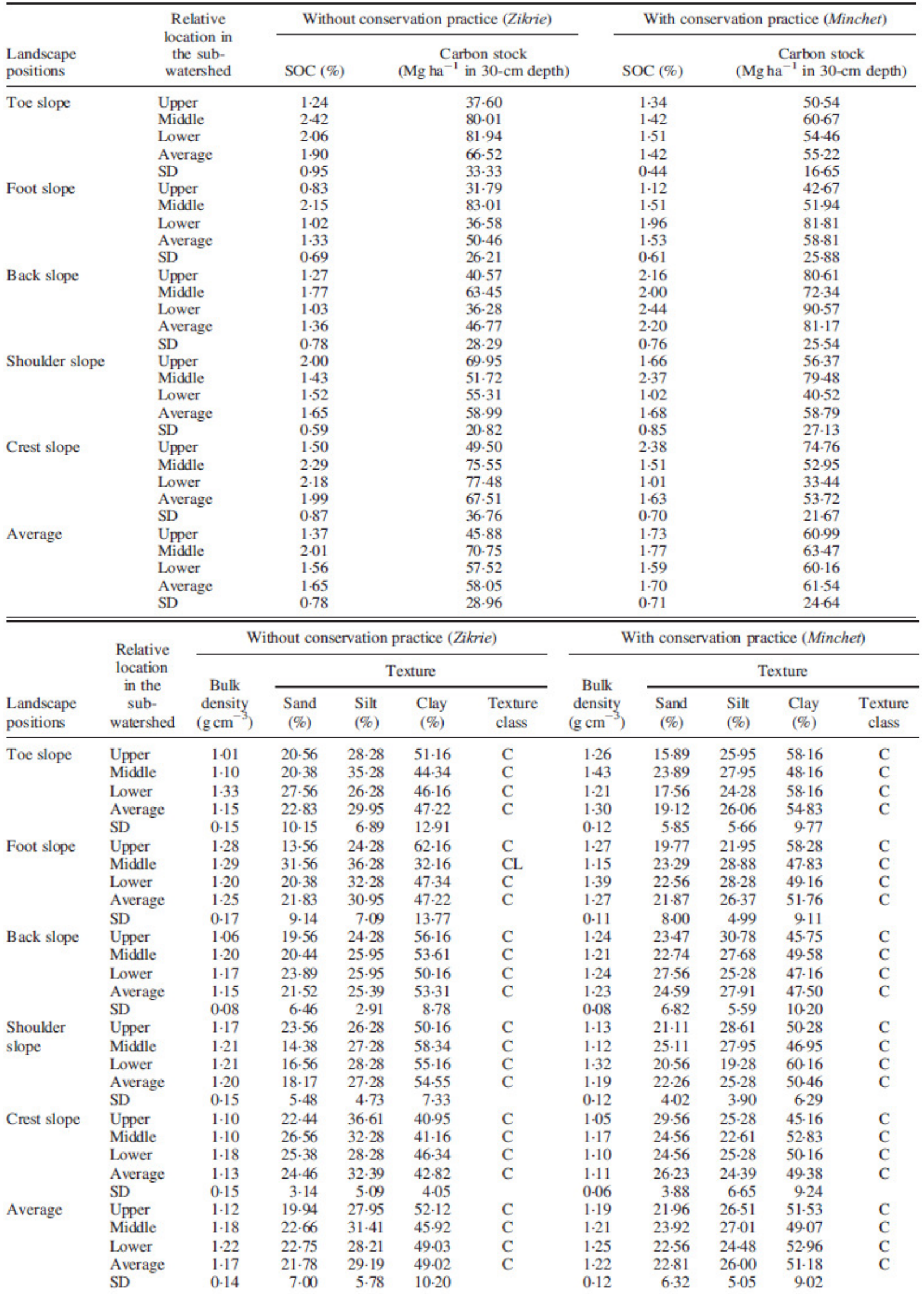


Appendix Table 11. Effect of Tied ridge on maize grain yield and biomass, Sankurra district SNNPR.

Effect on maize grain yield and Biomass

Table1. Maize grain yield and biomass on different practices

\begin{tabular}{lcccc}
\hline & \multicolumn{2}{c}{ Grain yld kg/ha } & \multicolumn{2}{c}{ BM kg/ha } \\
\hline Location & open tide ridge & Traditional & open tide ridge & Traditional \\
\hline $\mathbf{1}$ & 8500 & 6400 & 24713.3 & 20393.3 \\
$\mathbf{2}$ & 8200 & 5400 & 19833.3 & 15050 \\
$\mathbf{3}$ & 7700 & 6600 & 26766.6 & 22120 \\
$\mathbf{4}$ & 9000 & 6200 & 24710 & 17453.3 \\
Average & 8350 & 6150 & 24005.8 & 18754.15 \\
\hline
\end{tabular}

NB: yld-yield and BM-Biomass

Appendix Table 12. Effect of Terraces on selected soil properties, yield and yield components of Maize and Wheat, Dembecha district, Anjeni watershed

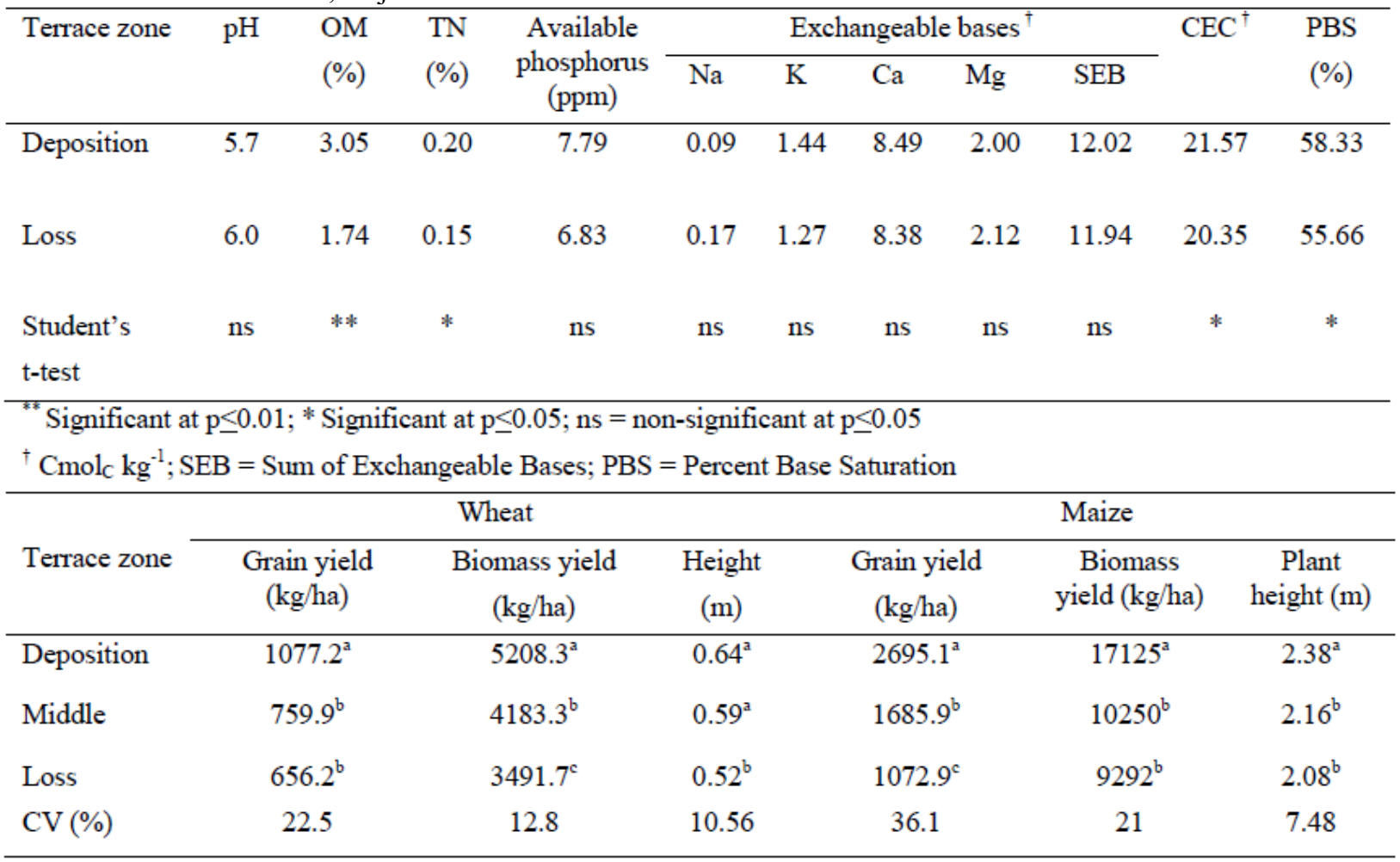

*Values in a column followed by the same letter are not statistically different at $\mathrm{p} \leq 0.05$ 